Scientific Journal Warsaw University of Life Sciences - SGGW

Problems of World Agriculture volume 18 (XXXIII), number 1, 2018: 80-87

DOI: 10.22630/PRS.2018.18.1.7

Anna M. Klepacka, ${ }^{1}$ Monika Bagińska ${ }^{2}$

Warsaw University of Life Sciences - SGGW

\title{
The Use of CSR Measurement Matrix in the Aspect of Sustainable Development
}

\begin{abstract}
The idea of Corporate Social Responsibility (CSR) represents the voluntary effort that companies invest in social life. Companies incorporate the concept of CSR strategy in their businesses, knowing its importance to the benefit of the public at large and to sustainable development. Any activity of any major company is exposed to public opinion, which plays a key role in shaping the image of the company. Companies compete to win social trust and acceptance of their activity. The aim of the article was to present the value and significance of CSR activities undertaken by companies, using the example of two businesses, i.e. Polski Koncern Naftowy (PKN) Orlen and Kompania Piwowarska in reference to sustainable development. The article compares the CSR measurement matrix that allows assessing whether a given company is socially responsible, to what extent CSR activities affect the company's stakeholders and to what extent they are consistent with sustainable development (assigning particular CSR development tools by Stakeholders applying the weights from 1 to 3). ISO 26000 standards define the principles of social and environmental responsibility as a guide for organizations and in the analysed companies are a tool that exerts one of the greatest impacts on stakeholders. For both companies, the most important stakeholders are Shareholders and Managers, and they are the ones who, to the largest extent, conduct a socially responsible dialogue for which all CSR development tools are important. Both companies conduct key activities, PKN Orlen used 91\% and Kompania Piwowarska 73\% of all CSR development tools considered in this study.
\end{abstract}

Key words: CSR, stakeholders, measurement matrix, sustainable development, Poland

JEL Classification: M14, Q01

\section{Introduction}

Corporate Social Responsibility (CSR) is a concept that is often discussed in both theory and management practice in recent years. The issue of social responsibility requires special attention due to social expectations, and the development and concentration of activities of many organizations in this area. Both in literature and in practical activities, there is an ongoing discussion about CSR. Corporate social responsibility means that the organization takes responsibility for the impact of its decisions and actions on society and the environment through transparent behavior (Stawicka, 2015). Globalization, which is a process of creation of "one world" or a global society (Kempny, 1998), blurs state boundaries and consolidation of regulations, principles, and rules, which are being adjusted to the society at large. Together with the integration of companies, development of Multinational Corporations and corporate globalization, the role of CSR expands throughout the whole supply chain in which the company operates. Representing a "huge strategy for political, social and economic change" (CSR Compendium, 2010), CSR is innovative enough to consider them global. According to

\footnotetext{
${ }^{1} \mathrm{PhD}$, Faculty of Production Engineering WULS - SGGW, 164 Nowoursynowska St., 02-787 Warsaw, e-mail: anna klepacka@sggw.pl; https://orcid.org/0000-0002-2828-5429

${ }^{2}$ MA, Faculty of Economics WULS - SGGW, 166 Nowoursynowska St., 02-787 Warsaw, e-mail: monika.baginska1993@gmail.com; https://orcid.org/0000-0002-2729-9757
} 
a CSR concept, enterprises voluntarily take into account social and environmental interests as well as relationships with stakeholders in building a business strategy (Wołoszyn et al., 2012). Stakeholders originally are defined as those who become affected or can affect the achievement of the firm's objectives e.g. employees, customers, shareholders, creditors, suppliers, and neighboring communities (Freeman, 1984).

The 21st century has witnessed growing interest in a concept of business management which is based on voluntary action, not only for financial profit or economic aspects, but with consideration to social and ecological interests as well. This business management concept is built on the foundations of ethics. Company activities affect owners, managers, and employees, but also customers and other entities whom a company may directly or indirectly impact. Companies are putting growing emphasis on the need to clearly define responsibility for each and every decision, and for all actions performed in relation to different persons and institutions (Hartmann, 2011). The corporate social responsibility that stands behind this concept is much more than the mere satisfaction of the legal and formal requirements mentioned by Friedman (1997), as it also incorporates sponsoring or taking up occasional charitable activities. The idea of corporate social responsibility departs from the traditional perception of an enterprise, company or organization as an autonomous business, which produces certain goods irrespective of the social situation in which it operates (Marrewijk, 2003); here, an organization is seen as a collection of certain interests that exist internally and externally. Whether the business will survive or not depends to what extent the expectations of its stakeholders are satisfied. The European Commission defines corporate social responsibility as an idea within the framework of which companies voluntarily incorporate social and environmental issues into their own business activities and in relations with their stakeholder groups (Green Paper, 2001). Kolter and Lee (2005) define CSR as a commitment to improve the well-being of society through voluntary business practices as a contribution of enterprise resources. The idea of CSR is characterized by an effective strategy of management, which conducts a social dialogue in the company's environment, leading to the company's growing competitiveness at a global level and simultaneously shaping favorable conditions for sustainable economic and social development.

In 2011 the European Commission defined CSR as the responsibility of enterprises for its impact on society. The Commission encourages companies to implement a process that will allow them to integrate into the fields of social, environmental, ethical and human rights together with the interests of customers and consumers. This will ensure close cooperation with stakeholders, which should be inscribed in the company's strategy ${ }^{3}$.

The concept of stakeholders was first raised by Edward Freeman in 1984. In his deliberations, Freeman pointed out that strategic success is based on human resources and relationships that the company has with suppliers, customers and other entities experiencing the impact of its operations. In one of his publications, he defined stakeholders as "any person or group of people who influences or is influenced by the organization's goals" (1990). Defining Corporate Social Responsibility clarifies its relationship and close connection with sustainable development. According to Adamczyk (2009), CSR is a commitment to the transparent and ethical conduct of business based on the principles of sustainable development. Thus, it can be stated that CSR is "a kind of business contribution to the implementation of the policy of sustainable economic development and a way of

${ }^{3} \mathrm{http} / /$ ec.europa.eu/enterprise/policies/sustainable-business/corporate-social-responsibility/index_en.htm (accessed 18.01.2018) 
running a company where the priority is to achieve a balance between its effectiveness and

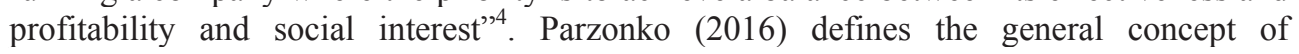
sustainable development as executing alongside economic goals also social goals, while taking into account environmental constraints. The ISO 26000 standard, one of the CSR development tools, defines it as the organization's commitment to involve environmental and social aspects in the decision-making process of the company and to take responsibility for the impact of the decisions made on the environment and society ${ }^{5}$. Social activities are creating an eco-friendly image of the region, with a special emphasis placed on the activities in the sustainable development area. In the future, the idea of CSR will possibly be developed also in rural areas (Klepacka and Bagińska, 2016).

Due to the growing importance of business and a reduction of many functions, countries should play a key role in the implementation of the CSR idea. Business exerts such a significant impact on the environment, it should reduce its negative effects and participate in counteracting threats in civilization (Jastrzębska, 2010). Enterprises are not able to meet these expectations when the basic goal of functioning is to remain economically viable. Then the question arises how to combine conflicting expectations, thus ensuring the development of enterprises? Do companies know the expectations of stakeholders and how they match to the expectations of companies? How can enterprises incorporate the expectations of stakeholders into the management process? The matrices of relevance allow examination of whether the enterprises take into account the expectations of their stakeholders in creating business strategies and, therefore, whether they are heading in the same direction as the customers. The literature on the subject outlines the tools that help define the attitude of the company towards the idea of CSR. There are many dimensions in which the organization can undertake socially responsible activities. Along with the growing popularity of CSR, many CSR development tools have emerged based on which companies can build their strategy, while at the same time, literature combines all indicators of advanced CSR activities into a measurement matrix that allows verifying the CSR company's advancement. An increasing number of enterprises and organizations declare their strategy to be compatible with the idea of CSR. It may happen that companies misinterpret the idea of Corporate Social Responsibility, and will try to improve their image to be more competitive by using CSR tools incorrectly. With this situation, there is a risk of companies that are not guided by CSR principles, but pretend to apply them. In order to compare company performance in terms of CSR, the authors propose the introduction of a CSR measurement matrix that will allow for verification of corporate declarations about social responsibility, and determine whether the company actually conducts a coordinated action in this area, or only declares it. The matrix is an important element allowing to increase the efficiency of activities and define in which areas the company is the most developed in the field of CSR, and it is possible to compare enterprises among themselves with benchmarking. With the matrix, we examine which elements of CSR strategy are present in the company and how strongly they influence specific stakeholders.

\footnotetext{
${ }^{4} \mathrm{http}: / /$ www.responsiblesme.eu/pl/baza-wiedzy-csr/co-to-jest-odpowiedzialny-biznes.html (accessed 23.01.2018)

${ }^{5} \mathrm{http} / / /$ www.mg.gov.pl/node/10892, Społeczna odpowiedzialność przedsiębiorstw (CSR) (accessed 23.01.2018).
} 


\section{Objective and methodology of research}

The aim of the article was to present the value and significance of CSR activities undertaken by companies, using the example of two businesses, i.e. Polski Koncern Naftowy Orlen (an oil company that owns many petrol stations in Poland), and Kompania Piwowarska (a Polish beer producer), in reference to sustainable development. The growing popularity of CSR affects the number of enterprises declaring their company's compliance with the assumptions of Corporate Social Responsibility, while some companies may use CSR to improve the company's image and thereby increase their competitiveness, creating the risk of superficial attitudes. The authors compared the CSR development tools in companies, assigning them weights from 1 to 3 , and assessed the significance for particular stakeholders of the company. The selection of these two companies was deliberate. The authors analyzed two industry sectors (fuels/energy/mining and consumer goods), applying the Rank of Socially Responsible Companies in the years 2007-2016 ${ }^{6}$. We selected 8 companies from each industry ${ }^{7}$. They were then analyzed by the 11 most popular and best described tools in the literature for supporting the development of CSR in enterprises: (Listed on the Respect $\operatorname{Index}^{8}(\mathrm{H})$, Listed on FTSE4Good ${ }^{9}(\mathrm{H})$, ISO $26000 \operatorname{standards}^{10}(\mathrm{H})$, GRI standards ${ }^{11}(\mathrm{H})$, The presence of the Book of Good Practices $\operatorname{FOB}^{12}(\mathrm{M})$, Reporting $^{13}(\mathrm{M})$, Good Contract Certificate ${ }^{14}(\mathrm{M})$, CSR Leaflets ${ }^{15}(\mathrm{~L})$, Information on the company website about $\mathrm{CSR}^{16}(\mathrm{~L})$, Listed in the CSR Ranking ${ }^{17}(\mathrm{~L})$, AA1000/SA8000 standards $\left.{ }^{18}(\mathrm{~L})\right)$. Each tool was assigned an importance ranking: $\mathrm{H}=\mathrm{High}(\mathrm{x} 3)$ - this is an important CSR tool that requires additional effort from the company, having a significant impact on its strategy and relations with stakeholders. These are also comprehensive tools that affect various areas of the company, hence the highest impact; $M=$ Average (x2) -

\footnotetext{
${ }^{6} \mathrm{http}: / /$ odpowiedzialnybiznes.pl/ranking-odpowiedzialnych-firm/ (accessed 16.01.2018).

7 According to the FOB Ranking, these companies received the highest number of CSR points in individual rankings in the period 2007-2016 from among all companies that participated in the Responsible FOB Ranking Companies scored according to the following criteria:

${ }^{8} 1$ - Listed on the Respect Index in the past, 2 - Listed on the Respect Index in the last year, 3 - Quotation on the Respect Index for the last 2 years in a row;

91 - Listed on FTSE4Good in the past, 2 - Listed on FTSE4Good in the last year, 3 - Listed on FTSE4Good for the last 2 years in a row;

${ }^{10} 1$ - The organization has expired certificate, b2 - The certificate has been valid for the last year, 3 - Certificate valid for the last 2 years;

${ }^{11} 1$ - Co-operation with GRI, but no complete report, 2 - Report in line with the GRU guidelines for the last year, 3 - Report in line with the guidelines for the last 2 years;

${ }^{12} 1-1-3$ practices reported for the previous year, $2->3$ practices reported for the previous year, $3->3$ practices reported for the previous 2 years;

${ }^{13} 1$ - CSR issues present in the annual report, 2 - A separate, comprehensive annual report informing about CSR activities and strategies, 3 - A separate, comprehensive annual report informing about CSR activities and strategies made at least for the second time;

${ }^{14} 1$ - Certificate obtained in the past, 2 - Certificate valid in the previous year 3 - Certificate valid for the previous 2 years;

${ }^{15} 1$ - Received White CSR Leaf, 2 - Silver Receipt of CSR Policy Leaf, 3 - Golden CSR Policy Leaf;

${ }^{16} 1$ - Information on CSR included in the general information about the company - only strategy, 2 - News on current CSR activities in the general / news section, 3 - A separate section on CSR with regular updates throughout the year (at least 2 times);

${ }^{17} 1$ - Listed in the ranking from 2 years ago, 2 - Listed in the ranking for the previous year, 3 - Listed in the ranking for the last 2 years in a row;

${ }^{18} 1$ - Applied in previous years but not verified, 2 - Verification of standards for the last year, 3 - Verification of standards for the last 2 years.
} 
these are tools that are easier to introduce from the organizational point of view, while their achievement is still important from the conceptual viewpoint of corporate social responsibility; $\mathrm{L}=$ Small (x1) - here we include tools that are not complicated to introduce, sometimes occur despite the lack of coordinated and deliberate actions. However, they are elements of corporate social responsibility. The above analysis allowed use to select one company from each industry, which in the next step was subjected to the evaluation of the impact of a given development tool on internal and external stakeholders of a given company ( 3 = high impact, 2 = medium impact, $1=$ low impact) (Freeman and Evan, 1990). The obtained values for each stakeholder show which values the organization focuses on the most, and on which the least. The matrix allows a clear and transparent assessment of whether the enterprise is socially responsible, and whether the performed activities affect the company's stakeholders. With this methodology, low results will be obtained by enterprises that only talk about CSR, but do not perform any activities that can be measured and controlled.

\section{Comparison matrix}

The CSR measurement matrix is a comprehensive tool enabling monitoring of results achieved by a given company in the area of corporate social responsibility. All single CSR development tools are described in detail in the literature, but simultaneously in this form such a matrix has not been compiled yet. The cyclical application of this matrix would allow the monitoring of results every year. By analyzing the results, a company gets information about areas where its strategy is the most powerful, and where there are still areas of weakness. When defining key stakeholders, thanks to the CSR measurement matrix, it is possible to check whether the company's activities build dialogue at a satisfactory level, or whether they require improvement. As a result of the previous data analysis, the highest rated companies from two economic sectors were selected - both companies are conducting advanced activities in the area of CSR.

Table 1. CSR measurement matrix in PKN Orlen S.A.

\begin{tabular}{|c|c|c|c|c|c|c|c|c|c|c|c|}
\hline $\begin{array}{l}\text { CSR development tools / } \\
\text { Stakeholders }\end{array}$ & 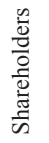 & 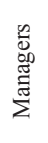 & 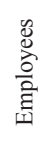 & 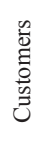 & $\begin{array}{l}\frac{n}{0} \\
\frac{0}{2} \\
0 \\
0\end{array}$ & 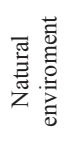 & 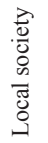 & 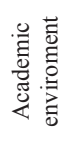 & O & 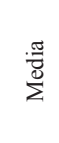 & $\stackrel{\pi}{0}$ \\
\hline $\begin{array}{l}\text { Listed on the Respect Index } \\
\text { Listed on FTSE4Good }\end{array}$ & 3 & 3 & 2 & 2 & 3 & 3 & 2 & 3 & 2 & 2 & 75 \\
\hline ISO 26000 standards & 3 & 3 & 3 & 3 & 3 & 3 & 2 & 3 & 2 & 3 & 84 \\
\hline GRI standards & 3 & 3 & 2 & 2 & 3 & 3 & 2 & 3 & 2 & 3 & 78 \\
\hline $\begin{array}{l}\text { The presence of the Book of } \\
\text { Good Practices FOB }\end{array}$ & 3 & 3 & 2 & 3 & 2 & 2 & 2 & 2 & 2 & 3 & 48 \\
\hline Reporting & 3 & 3 & 2 & 3 & 2 & 3 & 3 & 3 & 2 & 3 & 54 \\
\hline Good Contract Certificate & 3 & 3 & 2 & 3 & 2 & 2 & 2 & 2 & 2 & 3 & 48 \\
\hline $\begin{array}{l}\text { Information on the company } \\
\text { website about CSR }\end{array}$ & 3 & 3 & 2 & 3 & 3 & 3 & 3 & 3 & 2 & 2 & 27 \\
\hline Listed in the CSR Ranking & 3 & 3 & 2 & 3 & 2 & 2 & 2 & 2 & 2 & 3 & 24 \\
\hline CSR Leaflets & 3 & 3 & 2 & 3 & 2 & 2 & 2 & 2 & 2 & 3 & 24 \\
\hline AA 1000 / SA 8000 standards & 3 & 3 & 3 & 2 & 2 & 2 & 2 & 3 & 2 & 3 & 25 \\
\hline Total & 57 & 57 & 42 & 50 & 48 & 50 & 41 & 51 & 38 & 53 & 487 \\
\hline
\end{tabular}

Source: own study based on: Bargieł-Jeleńska D., Graczyk A. (2015); Boguszewicz-Kreft M. (2015); CSR Reports of the company PKN Orlen S.A. 
CSR development tools are closely associated with sustainable development. ISO 26000 standards define the principles of social and environmental responsibility as a guide for organizations and in the analyzed companies are a tool that exerts one of the greatest impacts on stakeholders. The standards of the Global Reporting Initiative promote the use of reporting in the field of sustainable development, and the mission of the organization is to disseminate and promote reporting on sustainable development, including $\operatorname{CSR}^{19}$. Hediger (2007) believes that there are many links between CSR and the sustainable development of agriculture, farm, economy or enterprise. As a Polish company, PKN Orlen is an unquestionable leader in supporting various sports disciplines in Poland. It chose to support sports because of its positive impact on millions of Poles. Additionally, the company is aware that sport has a huge communicative potential from the perspective of a marketing platform. The crucial notion of PKN Orlen is therefore sponsoring. Among the beneficiaries are selected disciplines or individual athletes, as well as the company's main brand and other commercial brands. As the company focuses on disciplines which best reflect its character, it usually chooses to sponsor volleyball, track and field or motorsports. PKN Orlen is not listed on FTSE4Good, hence the lack of data for this development tool. Compliance with ISO 26000 standard turned out to be one of the highest rated developmental elements of CSR in PKN Orlen. The company conducts a dialogue with every company stakeholder (see Table 1).

Table 2. CSR measurement matrix in Kompania Piwowarska S.A.

\begin{tabular}{|c|c|c|c|c|c|c|c|c|c|c|c|}
\hline $\begin{array}{l}\text { CSR development tools / } \\
\text { Stakeholders }\end{array}$ & 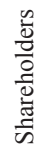 & 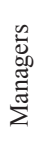 & 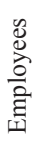 & 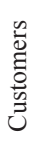 & $\begin{array}{l}\frac{\infty}{0} \\
\frac{0}{2} \\
0 \\
0 \\
0\end{array}$ & 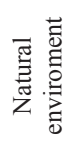 & 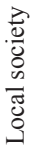 & 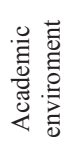 & O & $\sum_{\frac{\pi}{2}}^{\frac{\pi}{2}}$ & $\stackrel{\pi}{0}$ \\
\hline \multicolumn{12}{|l|}{ Listed on the Respect Index } \\
\hline \multicolumn{12}{|l|}{ Listed on FTSE4Good } \\
\hline ISO 26000 standards & 3 & 3 & 3 & 3 & 3 & 3 & 2 & 3 & 2 & 3 & 84 \\
\hline GRI standards & 3 & 3 & 3 & 3 & 3 & 3 & 2 & 3 & 2 & 3 & 84 \\
\hline $\begin{array}{l}\text { The presence of the Book of } \\
\text { Good Practices FOB }\end{array}$ & 3 & 3 & 2 & 3 & 2 & 2 & 2 & 2 & 2 & 3 & 48 \\
\hline Reporting & 3 & 3 & 3 & 3 & 2 & 3 & 3 & 3 & 2 & 3 & 56 \\
\hline \multicolumn{12}{|l|}{ Good Contract Certificate } \\
\hline $\begin{array}{l}\text { Information on the company } \\
\text { website about CSR }\end{array}$ & 3 & 3 & 3 & 3 & 3 & 3 & 3 & 3 & 2 & 2 & 28 \\
\hline Listed in the CSR Ranking & 3 & 3 & 2 & 3 & 2 & 2 & 2 & 2 & 2 & 3 & 24 \\
\hline CSR Leaflets & 3 & 3 & 2 & 3 & 2 & 2 & 2 & 2 & 2 & 3 & 24 \\
\hline AA1000 / SA8000 standards & 3 & 3 & 3 & 2 & 2 & 2 & 2 & 3 & 2 & 3 & 25 \\
\hline Total & 42 & 42 & 38 & 41 & 35 & 37 & 31 & 38 & 28 & 41 & 373 \\
\hline
\end{tabular}

Source: authors' own study based on: Bargieł-Jeleńska D., Graczyk A. (2015); Boguszewicz-Kreft M. (2015); CSR Reports of the company Kompania Piwowarska S.A.

\footnotetext{
${ }^{19}$ https://www.globalreporting.org/languages/polish/Pages/default.aspx (accessed 23.01.2018)
} 
Both analyzed companies occupy the leading positions in the Ranking of Socially Responsible Companies carried out by FOB in the years 2007-2016 ${ }^{20}$. PKN Orlen and Kompania Piwowarska are guided by the principles of CSR in creating business strategies, correctly interpreting its idea. For both companies, the most important stakeholders are Shareholders and Managers, and they are the ones who, to the largest extent, conduct a socially responsible dialogue for which all CSR development tools are important. The other very influential group of stakeholders in Kompania Piwowarska are clients and media for which the company's documented achievements in the area of CSR, such as issuing CSR reports of companies and its presence in the Book of Good Practices, are a very important element. The other influential group of PKN Orlen's stakeholders are the media and academic environment for which comprehensive annual reports informing about CSR activities and strategies are a very important element. Both companies conduct key activities, PKN Orlen used 91\% and Kompania Piwowarska 73\% of all CSR development tools cited in Tables 1 and 2.

\section{Summary}

Although the concept of CSR is intensively researched and applied around the world, and is gaining popularity in many countries, including Poland, it is still not a valid standard. The companies using matrices of relevance and taking into account the dialogue with stakeholders in the management of enterprise are socially responsible companies, appreciated and noticed by customers. Polluting the environment brings negative feedback from society. Yet the increasing attention of the media and NGOs and the growing global exchange of information have not caused a sudden growth of demand on the part of the society. A company which intends to attract and keep its employees and customers starts noticing the importance of CSR, including ethical conduct, in its day-to-day life.

CSR is becoming increasingly popular among companies which know how important and significant it is to conduct responsible business. All kinds of businesses are more and more exposed to public opinion, which plays a key role in the shaping of their image. Companies compete to win trophies such as social trust and acceptance of their activity. A number of them successfully implement certain CSR elements into their business strategies. Yet this tendency also raises concerns, as it makes it possible for companies to use their CSR image exclusively for making profits. Therefore, openness and transparency remain the key to responsible business.

Due to the fact that CSR is a continuous and long-term strategy, the repeatability criterion is also present in the matrix. It is not enough to report once on CSR to obtain a permanently high rating. The result must be maintained by continuing operations. In this way, companies that have a clear strategy and implement it every year will get positive results. Moreover, abandoning the use of any of the tools will be visible in the end result. By analyzing the results, the company gets information about areas where its strategy is the most powerful and where there are still areas in need of improvement. When defining key stakeholders, thanks to the CSR measurement matrix, it is possible to check whether the company's activities build dialogue at a sufficiently high level, or whether they require improvement. Sustainable development and social responsibility of business, are

${ }^{20} \mathrm{http}: / /$ odpowiedzialnybiznes.pl/ranking-odpowiedzialnych-firm/ (accessed 20.01.2018) 
not identical concepts, but the CSR concept fits into sustainable development, thus constituting the response of the geo-business sector to the challenges posed by the sustainable development principles that have become one of the three main priorities of the "Europe 2020" strategy ${ }^{21}$.

\section{Literature}

Adamczyk, J. (2009). Społeczna odpowiedzialność przedsiębiorstw: Teoria i praktyka (Social Responsibility of Enterprises: Theory and Practice), PWE, Warszawa.

Bojar, M. (red.) (2007). Społeczna odpowiedzialność w biznesie (Social Responsibility in Business), Wydawnictwo Politechniki Lubelskiej, Lublin.

Communication from the Commission to the European Parliament, the Council, the European Economic and Social Committee and the Committee of the Regions. A renewed EU strategy 2011-14 for Corporate Social Responsibility, Brussels (2011), COM(2011) 681 final.

CSR Worldwide. Revival. Mediaplanet. CSR Compendium (2010), 4/2010.

Freeman, R., Evan, W.M. (1990). Corporate Governance: a Stakeholder Interpretation. Journal of Behavioral Economics, 19(4), 337-359.

Freeman, R. (1984). Strategic Management: A stakeholder approach, Pitman Publishing, Boston.

Green Paper: Promoting Framework for Corporate Social Responsibility, Commision of the European Communities, Brussels (2001), COM(2001) 366 final.

Hartmann, M. (2011). Corporate Social Responsibility in the Food Sector. European Review of Agricultural Economics, 38(3), 297-324.

Hediger, W. (2007). Framing Corporate Social Responsibility and Contribution to Sustainable Development, Working Paper Series nr 02/2007, Center for CSR and Sustainability, University of Zurich.

Jastrzębska, E. (2010). Uczelnie wyższe a edukacja w zakresie społecznej odpowiedzialności biznesu (Universities and CSR Education). Zarzadzanie Zmianami. Zeszyty Naukowe, 2(20), 1-13.

Kempny, M. (1998) Globalizacja (Globalization). In: Encyklopedia socjologii, Oficyna Naukowa, Warszawa.

Klepacka, A.M., Bagińska, M. (2016). Corporate social responsibility and sustainable development of rural areas, Roczniki Naukowe SERiA, 18(5),78-86.

Kotler, P., Lee, N. (2005). Corporate social responsibility. Doing the most good for your company and your cause, John's Wiley \& Sons Inc., Hoboken.

Marrewijk, M. (2003). Concepts and definitions of CSR and corporate sustainability: Between agency and communion. Journal of Business Ethics, 44(2-3), 95-105.

Parzonko, A. (2016). Rola „drobnych” gospodarstw mlecznych w paradygmacie zrównoważonego rozwoju (The role of "small" dairy farms in the paradigm of sustainable development). Problemy Drobnych Gospodarstw Rolnych, 2, 63-84.

Rybak, M. (2006). Etyka menedżera - społeczna odpowiedzialność przedsiębiorstwa (Manager's ethics: corporate social responsibility), PWN, Warszawa.

Stawicka, E. (2015). Społeczna odpowiedzialność biznesu w praktyce na przykładzie sektora MSP w Polsce (Corporate Social Responsibility into Practice on the Example of the SME Sector in Poland). In: Nowe wyzwania dla Europy XXI wieku w dziedzinie zarzadzania i edukacji. Eds. M. Sitek, T. Graca, 255-269. Wyższa Szkoła Gospodarki Euroregionalnej im. Alcide De Gasperi w Józefowie. Józefów.

Wołoszyn, J., Ratajczak, M., Stawicka, E. (2012). Społeczna odpowiedzialność małych i średnich przedsiebiorstw agrobiznesu z obszarów wiejskich (Social Responsibility of Small and Medium-Sized Agribusiness Enterprises from Rural Areas), Wydawnictwo SGGW, Warszawa.

For citation:

Klepacka A.M., Bagińska M. (2018). The Use of CSR Measurement Matrix in the Aspect of Sustainable Development. Problems of World Agriculture, 18(1), 80-87;

DOI: 10.22630/PRS.2018.18.1.7

\footnotetext{
${ }^{21} \mathrm{http} / / /$ ec.europa.eu/eu2020/pdf/1_PL_ACT_part1_v1.pdf (accessed 23.01.2018).
} 